\title{
DEVELOPMENT AND PROSPECT OF INDONESIA SUSTAINABLE PALM GOVERNANCE IN THE COLLABORATIVE GOVERNANCE PERSPECTIVE
}

\author{
Wawan H. Hardiwinata, Doctor Candidate \\ Indah Mindarti Lely, Lecturer \\ Choirul Saleh, Lecturer \\ Soesilo Zauhar, Professor
}

Faculty of Administrative Science, University of Brawijaya, Indonesia

*E-mail: jurnalwawan2@gmail.com

\begin{abstract}
This study aims to analyze the Development and Prospects of Sustainable Palm Oil Management in the Perspective of Collaborative Governance. The location of the study was conducted at the secretariat of the ISPO Commission in Jakarta, the Indonesian Ministry of Agriculture, and the sustainable Indonesian palm oil parties involved in the ISPO commission. Data collection methods used is observation, interviews, and documentation. Data analysis uses the model of Miles, Huberman, and Saldana which consists of four activities, namely data collection, data condensation, data display, and conclusion drawing / verification (conclusion drawing / verification). The results showed 1) The development of ISPO-certified oil palm plantation companies has increased, in 2013 there were 10 companies increased to 40 companies in 2014, and increased quite dramatically in 2015 to 142 companies, in 2016 rose again to 184 companies. Until 2019, there were 621 with 607 companies, 10 self-supporting cooperatives, and 4 plasma cooperatives. 2) In 2016, of the 11.6 million hectares of total area of oil palm plantations in Indonesia, there were 1.5 million hectares of area that had applied the principle of sustainability under the ISPO system. (c) In 2019 there were 5,450,329 hectares, of which the plant would produce 3,178,823 hectares, and the total production of fresh fruit bunches (FFB) was 60,266,557 tons / year and CPO $13,003,424$ tons / year. Productivity is 18.96 tons / hectare and yields an average of $24.45 \%$. Even plantations that have implemented the ISPO system have not been guaranteed to be free from deforestation and social conflict. This is ironic because the area of oil palm plantations that have not yet received an ISPO certificate is much broader, which is 10.1 million hectares. This means that the potential destruction of natural forests and the escalation of social conflicts in the palm oil development sector in Indonesia will still not change significantly.
\end{abstract}

\section{KEY WORDS}

Development, prospects, palm, sustainable, governance.

Indonesia is known as an agrarian country which means a country that relies on the agriculture-plantation sector both as a source of livelihood, a major source of food and as a support for development in increasing economic growth in terms of: (i) the scope of its commodities, including various types of plants in the form of annual crops and crops one season, (ii) the results of their production are industrial or export raw materials, so that basically there is a link between business activities with various other sectors and subsectors, and (iii) their operations, mostly carried out by middle and lower class people spread across various regions (Goenadi, 2005) [1].

Agriculture-plantation is one of the sectors that is very dominant in community income in Indonesia (Dimas, 2014) [2]. This statement is evident from the majority of Indonesia's population working in the agricultural sector in 2014 which amounted to $41.18 \%$ or almost half of the working age population in Indonesia. Dimas (2014) [3] added that agricultural productivity is still far from expectations, where one of the factors causing the low agricultural productivity is human resources and interest in agriculture which is still very low in processing agricultural land and its results. The majority of farmers in Indonesia still use the 
manual system in processing agricultural land, resulting in competition. Didiek Goenadi (2005) [4] in the Agricultural Research and Development Agency Info, the Ministry of Agriculture added that the role of this sector in Indonesia could still be increased if it is managed properly despite not yet optimal cultivation.

In the agriculture sector, the plantation sub-sector is growing rapidly at this time. In the future, the great "hope" of the government for plantations can realize the development of areas outside Java, especially the border areas of the country as stated in the "TRIDHARMA" plantations, namely: 1) generate as much foreign exchange as possible, 2) help create employment opportunities, and 3) preserving natural resources (Mubyarto, 1989: 235). [5]

Oil palm plantations are one of the mainstay industry sectors that have attracted serious attention from the government, investors and farmers, especially since the 1990s. The development of oil palm in Indonesia has experienced rapid growth since 1970, especially in the 1980s to the present. Initially the oil palm plantations consisted of State Large Plantations (PBN) but in the same year also opened Private Large Plantation (PBS) and Smallholder Plantation (PR) through the PIR (Smallholder Plantation) pattern and subsequently a self-supporting pattern developed. In 1980 the total area of oil palm was 294,000 ha and in 2009 the area of oil palm plantations had reached 8.32 million ha in which $47.78 \%$ was owned by PBS, $43.71 \%$ was owned by PR-People, and $8.41 \%$ was owned by PBN. In fact, the development of oil palm plantations has now expanded to almost all major islands in Indonesia, until 2014 oil palm plantations reached an average growth of 578,000 $\mathrm{Ha} /$ year or around $13.96 \%$ per year. Until 2009 Indonesia had approximately 11.5 million hectares of oil palm land (BPS, Palm Oil Statistics 2014). It is estimated that in 2019 it will reach 16.3 million hectares.

Palm oil is Indonesia's export commodity which is quite important as the country's largest foreign exchange earner leaving oil and gas in 2017. Starting in 2006 Indonesia was able to catch up with Malaysia which was previously ranked first in the affairs of palm oil, so that in 2014 Indonesia was an oil producing and exporting country the largest palm oil in the world with a total production of 30.9 million tons and in 2016 amounting to 35 million tons of palm oil, then followed by Malaysia with a total production of 20.62 million tons. Production of the two countries reached $85 \%$ of world production which amounted to 55.11 million tons. Indonesia is the largest palm oil producing country in the world, but until 2014 most of the palm oil exports from Indonesia were in the form of raw materials so that the added value obtained was relatively small. In 2014 exports of palm oil and its derivatives were $83.97 \%$ in the form of Crude Palm Oil (hereinafter abbreviated as CPO), $14.25 \%$ in the form of palm kernel oil and only $5.38 \%$ in the form of derivative products, while in Malaysia, the majority the export of palm oil commodities in derivative products (BPS, Statistics of Palm Oil 2014). However, from June 2015 to December 2016 there has been a significant change in Indonesia's palm oil exports to $30 \%$ CPO and $70 \%$ CPO-derived products (BPDP Palm Oil 2016).

Oil palm development, among others, provides benefits in increasing the income of farmers and the community (income of oil palm farmers in 2010 is projected to be around USD 2,000-2,500 / household / year from around USD 1,246-1,650 / household / year in 2005): which is the raw material for the processing industry which creates added value in the country and for export as foreign exchange earners (production in 2000 by 7 million tons increased to around 35 million tons in 2016): CPO exports which generate foreign exchange (export volume in 2000 was 4, 11 million tons valued at USD 1.09 million increased to 30 million tons valued at USD 18.76 million in 2016): in 2005 provided employment opportunities for more than 2.8 million workers in various subsystems and became around 12 million direct and direct workers 20 million indirect workers in 2016.

Palm oil is currently a very reliable commodity, because oil palm has provided the country's highest foreign exchange compared to other national export commodities. This large contribution can be seen in the growth of CPO which reached the top rank for non-oil and gas export performance in the period from January to August 2014 with export value reaching 5,385.7 million US $\$$ and becoming 30 million tons with a value of around 18.7 
million US $\$$ at the end of 2016. The significant contribution of exports from palm oil is due to increased demand for world palm oil exports, due to the tendency of world palm oil consumption which continues to increase in line with world population growth (BPDP Palm, 2016).

Table 1 - Development of Area, Production and Productivity of Indonesian Palm Oil

\begin{tabular}{|c|c|c|c|c|c|c|c|c|c|c|}
\hline \multirow{2}{*}{ YEARS } & \multicolumn{2}{|c|}{ PEOPLE'S PLANTATION } & \multicolumn{2}{|c|}{$\begin{array}{l}\text { PLASMA PEOPLE'S } \\
\text { PLANTATION }\end{array}$} & \multicolumn{2}{|c|}{$\begin{array}{l}\text { LARGE COUNTRY } \\
\text { PLANTATION }\end{array}$} & \multicolumn{2}{|c|}{$\begin{array}{c}\text { PRIVATE } \\
\text { VOCATIONAL } \\
\text { PLANTATION } \\
\end{array}$} & \multicolumn{2}{|c|}{ TOTAL } \\
\hline & Area $(\mathrm{Ha})$ & $\begin{array}{c}\text { CPO } \\
\text { Production } \\
\text { (Tonnes) }\end{array}$ & Area $(\mathrm{Ha})$ & $\begin{array}{c}\text { CPO } \\
\text { Production } \\
\text { (Tonnes) }\end{array}$ & $\begin{array}{c}\text { Area } \\
(\mathrm{Ha})\end{array}$ & $\begin{array}{c}\text { CPO } \\
\text { Production } \\
\text { (Tonnes) }\end{array}$ & Area $(\mathrm{Ha})$ & $\begin{array}{c}\text { CPO } \\
\text { Production } \\
\text { (Tonnes) }\end{array}$ & Area $(\mathrm{Ha})$ & $\begin{array}{c}\text { CPO } \\
\text { Production } \\
\text { (Tonnes) }\end{array}$ \\
\hline 2010 & $2,709,805$ & $5,921,096$ & $677,451.40$ & $2,537,613$ & 631,52 & 1.890 .503 & $4,366,617$ & 11.608 .907 & $7,753,874$ & $21,958,119$ \\
\hline 2011 & $3,001,984$ & $6,158,546.80$ & $750,496.00$ & $2,639,377$ & 678,378 & 2.045 .562 & $4,561,966$ & 12.253 .055 & $8,992,824$ & $23,096,541$ \\
\hline 2012 & $3,310,096$ & $6,438,409.60$ & $827,524.00$ & $2,759,318$ & 683,227 & 2.133 .007 & $4,751,868$ & 14.684 .783 & $9,572,715$ & $26,015,518$ \\
\hline 2013 & $3,484,869$ & $7,007,509.60$ & $871,217.40$ & $3,003,218$ & 727,767 & 2.144 .651 & $5,381,166$ & 15.626 .625 & $10,465,020$ & $27,782,004$ \\
\hline 2014 & $3,641,483$ & $7,478,300.20$ & $910,370.80$ & $3,204,986$ & 748,272 & 2.156 .294 & $5,656,105$ & 16.504 .899 & $10,956,231$ & $29,344,479$ \\
\hline 2015 & $3,791,988$ & $7,918,848.00$ & $947,997.20$ & $3,393,792$ & 769,357 & 2.201 .634 & $5,935,465$ & 17.434 .658 & $11,444,808$ & $30,948,932$ \\
\hline $2016^{*}$ & $3,905,748$ & $8,314,790.40$ & $976,437.12$ & $3,563,482$ & 792,438 & $2,311,716$ & $6,113,529$ & $18,306,391$ & $11,788,152$ & $32,496,379$ \\
\hline
\end{tabular}

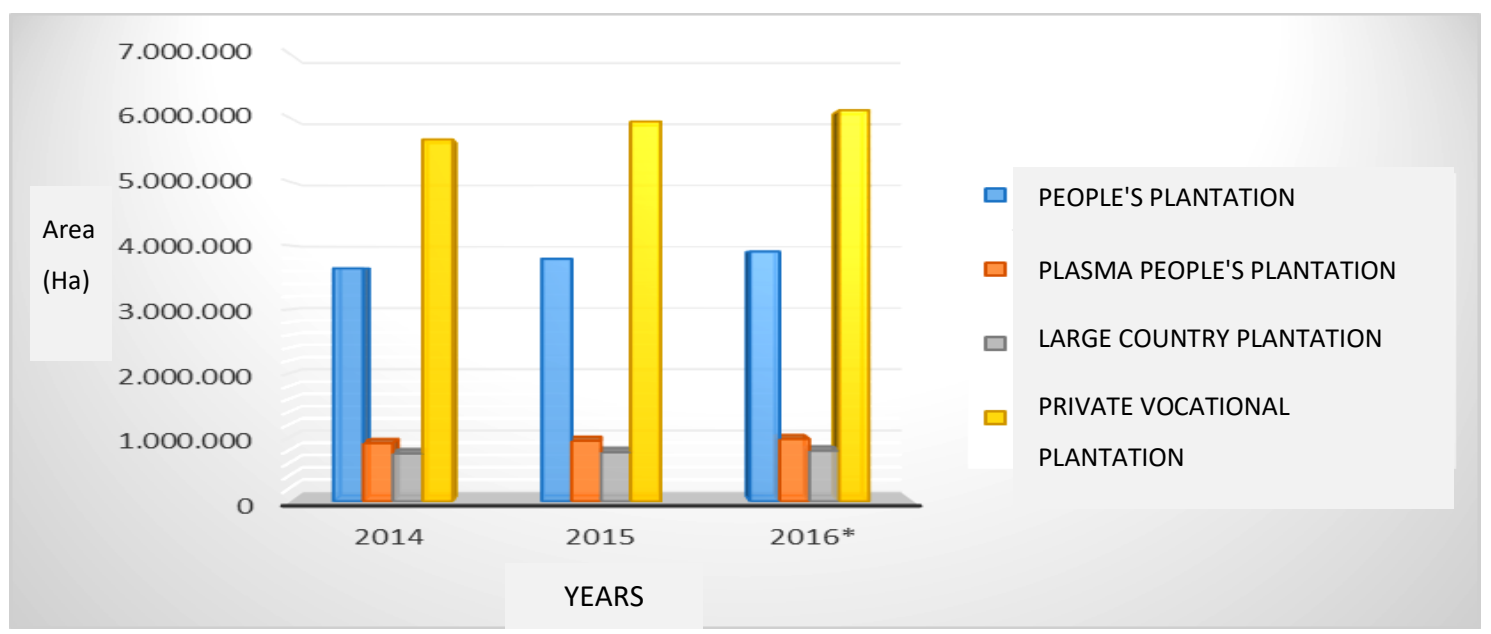

Source: 2017 Directorate General of Plantation, BPDP-KS 2017.

Figure 1 - Chart of Indonesian Palm Oil Production until 2016 (GAPKI, BPDPKS, DITJENBUN 2017)

In relation to the determination to have a sustainable development system for the palm oil industry, aside from resting on the reasons of Indonesia as the world's largest producer of palm oil, it is more important to emphasize that the Indonesian people are very concerned and impossible to turn a blind eye to global issues in the field of sustainability. The implementation of sustainability principle policies in the development of Indonesian palm oil is based on: 1) international commitments; 2) 1945 Constitution; 3) Law Number 18 of 2004 concerning Plantations; 4) reference to buyer demands and commitment from producers; 5) The European Union and its entire overseas network will only buy sustainable palm oil in 2015. In addition, it is also guided by the International Commitment under the UNCED (UN) Agenda 21 (Global Program of Action on Sustainable Development), namely: 1) Rio Earth Summit 1992; 2) Earth Summit +5 1997; 3) World Summit on Sustainable Development 2002 (Johannesburg); 4) International Conference on Financing Development (DOHA Round) Monterey Consensus. Where the result, this UN organization asked all 178 countries to implement sustainable development principles.

The basis and orientation of the Governance for the development of the palm oil industry above is that ISPO in general has referred to governance reforms originating from around 130 legislation (ISPO Commission 2016) [6] which can serve as guidelines for the development of a sustainable palm oil industry. The policy aims to ensure that the development of the Indonesian palm oil industry is balanced and synergistic in terms of the environment, socio-culture and economy. 
Past experience shows that Indonesia's oil palm management policies tend to leave problems, both laborers with low wages, socio-cultural impacts of the emergence of conflicts around oil palm plantations, as well as environmental impacts whose management is detrimental to the general public such as forest fires where the effects of haze can adversely affect health and disrupted economic activity. The past policy of oil palm is considered to have become a nightmare in managing oil palm in Indonesia, leaving environmental, social and economic problems.

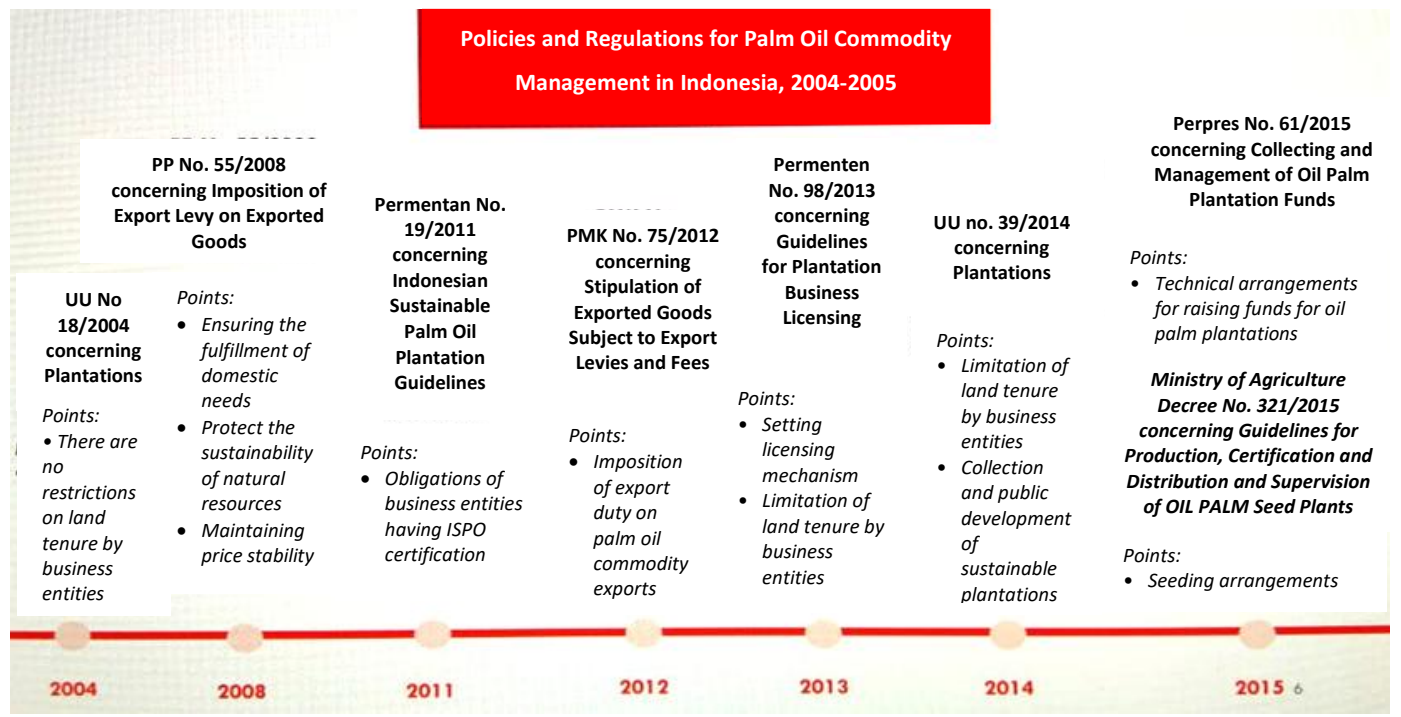

Figure 2 - Development of the Indonesian Palm Oil Administration Policy

In general, issues and problems of perelawawitan so far can be grouped into two sides, namely the production side (supply side) and the consumption side (demand side). Issues and problems from the production side, namely: Considered as the cause of environmental damage, the cause of forest fires \& deforestation, voracious water (the cause of drought vs. flooding), decline / death of protected animals, cause global warming and climate change, greenhouse gas emissions, palm oil as an unhealthy oil, marginalized indegeneous people, conflicts around the plantation, welfare of workers and underage workers, and no less important is the problem of delaying the rejuvenation of Indonesian palm oil for ten years compared to Malaysia, and is likely to follow subsequent accusations systematically, "As long as Oil Palm Can Not Be Cultivated in Europe \& the USA".

While the demand side problem (Demand Side), namely the level of "acceptance" of Indonesian palm products is still low because of the demands of consumers and international markets, especially Europe and America, requires that the Indonesian palm production system must be $100 \%$ compliance on the principle of sustainability, resulting in unstable CPO prices, even Indonesian palm oil has continued to experience international pressure and experienced price declines since 1997. This certainly requires good governance so that Indonesian palm oil comes out of the threat of sustainability as the nation's economic potential and has become the country's number one foreign exchange earner since 2015.

Indonesia's palm oil governance is currently carried out based on the provisions of the main plantation regulations namely RI Law No. 39 of 2014 concerning Plantations and their derivatives, Indonesian palm oil is carried out by large business actors (private and state) and Plantation-Farmers. Institutions / institutions related to their functions and roles in the current management of Indonesian palm oil are as follows: The Coordinating Ministry of the Republic of Indonesia (Coordinating of the Indonesian Palm Sustainability National Policy); The Indonesian Ministry of Agriculture (Palm Upstream Licensing and Technical Management); Ministry of Agriculture and Spatial Planning - ATR / BPN (Licensing, HGU, and Land Use); Ministry of Forestry and the Environment (Licensing for Forest Area Governance and Environmental Management); Ministry of Trade (Palm Licensing, Promotion 
and Advocacy); Ministry of Industry (Licensing and Governance of Downstream Palm Industry); Ministry of Manpower (Worker Safety Licensing and Governance); Ministry of Cooperatives and Small and Medium Enterprises (Licensing and Governance of People's Palm and Cooperative Cooperatives); Ministry of Energy and Mineral Resources (Licensing and governance of palm oil Bio-Energy-Biodiesel); Ministry of BUMN (Licensing and Governance of State-owned Palm Oil Companies); Ministry of Finance (Licensing and Governance of state finances for Indonesian palm oil); Ministry of PPN / Bappenas (Indonesian National Palm Oil Development Planning in accordance with RPJPM); Ministry of Foreign Affairs (Advocacy and Diplomacy of Indonesian Palm Oil); National Standardization Agency (Indonesian Palm Standard / ISPO); Provincial / District Government (Licensing, Fostering Partnerships, and Business Evaluation of Oil Palm Plantation): ISPO Commission (ISPO Certification and ISPO Auditor Training); Palm Oil Plantation Fund Management Agency-BPDP (Collecting, Managing and Distributing Palm Funds specifically for Indonesian palm oil).

Investment in oil palm plantations on an ongoing basis is threatened to fall in line with the lack of incentives received by businesses for certified palm oil products. Managing Director of Sustainability and Strategic Stakeholders Engagement at Sinarmas Agribusiness and Food Agus Purnomo said that low price fluctuations and oil absorption were the main obstacles in realizing sustainable plantations. The production of Roundtable Sustainable Palm Oil (RSPO) is 13 million tons, only 7 million tons are absorbed by the European Union. Agus said that slowly, the demand for green crude palm oil (CPO) products is decreasing. In fact, local producers are able to produce CPO certified greater than market demand. According to him, if the absorption of certified CPO decreases, the development of sustainable oil palm plantations also decreases. Because, until now, palm oil producers are still dependent on the European Union market to sell sustainable palm oil (sustainable palm oil / SPO). According to him, there was a kind of campaign in the Blue Continent to corner the product with palm raw materials. In fact, demands for sustainable products have been met. "Palm oil anti-virus is everywhere". If now only energy might later move to cosmetics, medicine and food. It's not the energy that is being pursued, but the palm oil is the enemy" (Septian, 2015) [7].

Strong pressure over the past few years, which mainly comes from international NGOs and NGOs from western consumer countries, has prompted several large companies to announce a commitment to sustainability that is further from Indonesian legal requirements. Although this commitment is welcomed by civil society and other stakeholder groups, more and more parties are recognizing that implementing this commitment on the ground will be very difficult. This is due to conflicting government regulations, which for example encourage companies to avoid impacts on protected species, but prevent companies from maintaining conservation areas set aside in their plantations. A further challenge is that commitments free from deforestation have not been well received by most domestic palm oil producers, especially those of medium and small scale and small farmers operating in areas where there is a lot of new deforestation.

These things raise awareness of the need to build a sustainable palm oil constituency in the country in order to provide market incentives to all actors in the supply chain and political pressure to make regulatory changes. Kadin Indonesia, for example, is developing strategies to create and strengthen such constituencies. Other initiatives from NGOs, other members of civil society, and industry groups that have been certified by ISPO / RSPO, can help build momentum to expand commitments to include a variety of producers.

There are four main decision points that determine the cumulative scale of deforestation and peatland conversion related to oil palm, namely: 1) Where oil palm is planted as a result of decisions made on spatial planning, licensing, and estate planning and development; 2) How much oil palm is planted, which is driven by domestic and international demand and prices, yields per ha, taxes and duties, government planting targets, and government biofuel policies; 3) How off-site activities related to oil palm development are managed (for example, road construction and population growth related to plantations); and 4) How leakage of deforestation from other competing land uses is handled. Among these 
four factors, the series of decisions that determine where oil palm is planted has the greatest and most complicated deforestation impact to address.

The bad policies and practices of the oil palm plantation industry have contributed to agrarian conflicts in 659 cases, with 208 cases occurring in the plantation sector, with an area of 530,491.87 hectares of land and at the expense of 652,738 families. (Elsam, 2010) [8]. The controversy over oil palm plantation governance policies triggered an echo of community advocacy in fighting for their rights increasingly echoing. In this democratic system, community involvement in the public policy process is increasingly showing its prowess. So as to provide space to present participatory policies (bottom up) along with top down policies. (Santoso, 2004) [9].

The idea that public policy is not present in a vacuum is very relevant for further study. It has been proven that palm oil governance raises many problems, including: 1). Abuse of Authority in the issuance of Permits (Post the issuance of PP 34 of 2002). For example: issued by the Governor and Regent, even though the authorized person is the Minister of Forestry 2). Giving permission is not according to the designation. (a) oil palm may only be used in Other Use Areas (APL), if in the forest the status must be changed to non-forest area; (b) HTI may not be cleared as a non-forest area; (c) HTI may not be cleared in productive production forests. 3) Bribery and Gratification of central / regional officials for the issued permit; 4) Officials are given "free shares" in a Palm company (Palm Watch, 2011). In another part, there is a mafia mode in the forestry sector law, violations of the spatial planning of forest areas into oil palm plantations.

Various problems that develop in oil palm plantations should be carried out by public policy interventions in governance that can benefit all stakeholders. Governance which is a translation of governance, basically governance focuses more on the interactions that occur between the three actors namely the government, the business / private sector, and the community. The essence of governance is to strengthen the interaction between the three actors in supporting people-centered development (Cheema, 2007: 34-35) [10]. The definition of governance itself is as an interaction between government and society (citizens) that allows programs and public policies to be formulated, implemented and evaluated. In a broader context, governance leads to rules, institutions and networks that determine how an organization or country functions (Bhatta, 2006) [11]. Neo and Chen (2007) [12] describe governance as a step, policy, and institution chosen as well as the resulting structure that collectively provides incentives and obstacles to facilitating or preventing interaction in achieving progress in the social and economic fields.

The key word for the concept of governance is a consensus where differences in interests can be accommodated and synergies can be built through that consensus. With governance, it is expected that State institutions can work and run well in addition to strengthening market institutions and also civil society to compensate for the dominance of the State which was previously deemed incapable in carrying out development (Pratikno, $2005,236)$ [13]. Then thought developed about the role of government which is no longer central in people's lives but seeks to transform the entrepreneurial spirit into the public sector, with the emergence of the book "Reinventing Government" (1992) by David Osborne and Ted Gaebler. Next came New Public Services (2003) by J.V. Denhardt and R.B. Denhardt where the government is more oriented to citizen-centric governance, not institution-centric vicil service (Prahalad, 2005) [13]. Then the last thing concerns the governance paradigm, where the role of government is more facilitator and enabler, which provides an opportunity for the community to play an active role as social economic actors. In the development of the concept of governance, discourse emerged regarding the concept of good governance. Good governance according to UNDP (United Nations Development Program) has the following characteristics (Rondinelli, 2007: 7) [15]: Participation, Rule of law, Transparency, Responsiveness, Consensus orientation, Equity, Effectiveness and efficiency, Accountability, and Strategic vision. Healthy good governance will also develop healthily under an authoritative leadership and have a clear vision (Effendi, 2005) [16].

In collaborative governance according to Ansell and Gast, an arrangement that regulates one or more public institutions together with non-State actors and stakeholders 
directly involved in the collective decision making process that is formal, consensus-oriented, and deliberations aimed at making or implementing public policy or managing public programs or assets (Ansell and Gash, 2007) [17].

Khususiyah, et al. (2009) [18] from his research explained that the community-based forest resource management system (PHBM) that functions for oil palm development is carried out with the principle of shared, empowered and shared in terms of land use, time and results in the management of forest resources with the principle of mutual benefit, strengthen and support and awareness of social responsibility. Dewi (2011) [19], good governance is needed to build and organize responsible management structures and processes that can open, facilitate, and provide opportunities and forums for dialogue that are constructive, sharing information, communicating and making decisions together- same for various problems. Governance means the establishment and maintenance of a collaborative structure and process for managing a business or business across stakeholders, which includes government, business / industry, and the community. In addition, the involvement of stakeholders who play a key role in decision making needs to be accompanied by an increase in their respective capacities to support a responsible governance system. Therefore, responsible governance requires creating conditions and situations that are conducive to good collaborative governance.

Ade Febrian $(2016,200)$ [20] the involvement of various parties in rural area development has the potential to advance the village by collaborating with the available resources. Collaboration starts from the development plan discussed by the Central Government, Provincial Governments, District / City Governments, and Village Governments and even from the village to the central level through a consensus. The problem that occurs in this context is seen from the concept of Collaborative Governance is the lack of running the system Context seen from the changing conditions of legislation, drivers seen from the leadership element that greatly affects development planning in the village, and the dynamics of collaboration that occur are unfavorable conditions all parties so that sectoral egos still occur. The concept of Collaborative Governance as an alternative basis is considered capable of realizing the acceleration and implementation of rural areas as a solution for those who will develop and implement rural areas in the form of policies or research.

In general it is explained that Collaborative Governance is a process in which various stakeholders are involved to carry the interests of each agency in achieving common goals. (Cordery, 2004 [21]; Hartman et al., 2002) [22]. Oil palm plantation is one of the mainstay industry sectors that attracts serious attention from the government, investors (private) and farmers (community) who are never devoid of the dynamics of conflict problems among stakeholders as described above. Therefore this research will explore "Sustainable Palm Oil Management in the Perspective of Collaborative Governance", which was conducted at the ISPO System of the Ministry of Agriculture of the Republic of Indonesia.

Formulation of the problem. In order to obtain clarity on the application of theory and understanding of the problems in the framework of Sustainable Indonesian Palm Governance in Collaborative Governance Perspective, the formulation of this research is "What is the Development and Prospect of Sustainable Indonesian Palm Governance in the Collaborative Governance Perspective?".

Research purposes. This study aims to analyze the Development and Prospects of Sustainable Palm Oil Management in the Perspective of Collaborative Governance.

\section{METHODS OF RESEARCH}

This research is a qualitative research, historical in character with descriptive analysis. The reason for using this qualitative method is because the problem of sustainable palm governance is unclear, holistic, complex, dynamic and meaningful so it is not possible to capture data on social situations like this with quantitative research methods, in addition to that the researcher also intends to understand social situations in depth, find patterns about the analysis of sustainable palm governance in the perspective of collaborative governance. This type of research in this case is a case study, namely research that seeks to find 
scientific truth by studying in depth over a long period of time. From this design, a picture of the phenomenon of the research problem, the facts of the problem, the nature and relationship between the phenomena of the Indonesian oil palm governance in a Collaborative Governance perspective can be seen. After all is complete, the categorization of that fact is carried out and then enters the hypothesis formulation stage as research findings. This is a new proposition which is the end of the research conclusion.

The focus of this research is the Development and Prospects of Sustainable Palm Oil Management in the Perspective of Collaboration Governance.

The location of the study was conducted at the secretariat of the ISPO Commission in Jakarta, the Indonesian Ministry of Agriculture, and the Indonesian sustainable palm oil parties involved in the ISPO commission, with the following reasons:

1. The importance of Indonesian palm oil as a source of state income and being able to become a potential mainstay for the Indonesian state and society, its distribution is evenly distributed in Sumatra, Sulawesi, and Kalimantan and Papua. When incorporated with ISPO, the sustainability and sustainability of oil palm plantations can be guaranteed.

2. ISPO is a new concept of sustainable Indonesian palm governance that is expected to be able to strengthen and increase the acceptance of Indonesian palm oil in the international market. For this reason, ISPO has a secretariat where the ISPO commission is active in overseeing sustainable Indonesian palm oil management.

Specifically, the data and information needed in this study were obtained from various parties. These parties are the government (Ministry of Agriculture of the Republic of Indonesia), Provincial and Regional Governments, Village Governments, oil palm business associations, large companies, medium-sized companies and smallholders, and communities and NGOs concerned with Indonesia's sustainable palm oil policy.

Basically, qualitative research emphasizes more on direct data from social phenomenon actors or people who know and or experience the phenomenon as interviewed informants. Because it is more about building a framework and problems, anyone can be a source of data as long as it remains consistent with the research problem.

According to Lofland and Lofland (Moleong, 2007) [23] the main data sources in qualitative research are words and actions, the rest are additional data such as documents and others. However, to complete the research data, two data sources are needed, namely the primary data source and the secondary data source.

a. Primary Data Sources. Primary data is data collection with observation instruments, interviews, field notes and use of documents. Primary data sources are data obtained directly by interviewing informants or direct sources. Primary sources are data sources that directly provide data to data collectors (Sugiyono, 2015: 187) [24]. As in this study primary data sources were obtained from observations, events, and direct interviews with palm business actors: (PBS, PTPN, Farmers / Planters),

b. Secondary Data Sources. Secondary data sources are data used to support primary data through literature studies, documentation, books, magazines, newspapers, written archives relating to the object to be examined in this study. Secondary data sources are sources that do not directly provide data to data collectors, for example through other people or documents (Sugiyono, 2015: 187) [25]. Secondary data sources in this study include regulators or policies issued by the Ministry of Agriculture and other related Ministries, Provincial Governments and Local Governments related to the palm oil industry. And other data includes; archive of performance reports and documents / other data relating to research problems.

Data Collection Methods and Research Instruments. The data collection technique used in this study is to use free (non-structured) interviews. Conduct participant observation, examine documents based on the source and type of data, conduct field reviews with direct observation of symptoms and social interactions. Words are arranged based on actions while comparing written sources (documents), field notes, maps and statistical data. To obtain the information and research data needed, the researchers conducted through two main techniques such as the model developed by Lofland (1984) [26], namely: 
- In-depth interview. The initial step to carry out this activity is the researcher first prepares a research instrument including interview guidelines as part of the research instrument recommended by the Promoter.

- Document Study. This technique is carried out to obtain secondary data that is carried out by collecting data sourced from the archives at each site as well as the research location. In this case the information comes from various archives and other documents which are deemed necessary and relevant to the problem being studied and researched.

- Observation. Researchers as research instruments conduct in-depth interviews and observations. Through continuous observation in order to establish important and less important aspects by referring to the dimensions studied. Through careful observation, intended to be able to see symptoms in the reality of daily life activities (Koentjaraningrat; 1982). [27]

The research instrument is a tool used by researchers to conduct research. There are two main things that affect the quality of the resulting data, the quality of research instruments, and the quality of data collection.

According to Sugiyono (2012: 61) [28] in qualitative research the main instrument is the researcher himself, but later after the focus of the research becomes clear, it is possible to develop a simple research instrument, which has been discovered through observation and interviews. Researchers will dive into their own field, both on the grand tour questions, the focused and selection stage, conducting data collection, analysis and making conclusions.

Furthermore Nasution in Sugiyono (2012: 60-61) [29], states in qualitative research, there is no other choice than to make humans as the main research instrument. The reason is that everything doesn't have a definite form. Problems, research focus, research procedures, hypotheses used, even expected results, all of which can not be determined with certainty and clearly. Everything still needs to be developed in the research. In this uncertain and uncertain situation, there is no other choice and the researcher himself as the only tool can achieve

According to Sugiyono (2012: 222) [30] what became an instrument or research tool was the researcher himself. In this study, the research instruments used were:

a. The researcher himself is the main instrument in capturing or seeing phenomena directly through interviews. According to Moleong (2014: 78) [31], one of the characteristics of qualitative research is to include human beings or researchers themselves as the main data collection tools. That is because, in conducting qualitative research, both observations and interviews may not be represented by others, so that researchers can capture phenomena or events that occur in the field and be able to master the data that has been obtained in the field.

b. Interview guide (interview guide), this instrument is useful to direct and limit researchers in searching the data needed through interviews that will be carried out. This interview guide was made by the researcher before conducting the interview so that when interviewing with the informant, the researcher already has a list of questions and desired data and can deepen the information data that has been obtained previously.

c. Field notes (voice notes), voice recorders, and photos via mobile phones, and stationery. In conducting research, researchers need field notes to record the phenomenon of the object under study, then the phenomenon can be recorded using a voice recorder or photographed using a cellphone (cellphone) as a support and reinforcement in collecting information data.

Data Validity. Every research requires a standard to see the degree of trust or truth of the research results. In qualitative research these standards are often referred to as data validity. The validity of the research data was attempted through the application of the criteria advocated by Lincoln \& Guba, and Moleong (1991) [32].

1. Trust The application of this criterion is done through interviews and observations. Triangulate by cross checking data with relevant agencies at the central and regional levels, as well as cross checking with other informants from the community. In 
addition, the authors conducted discussions with peers who were considered to have knowledge and intellectual sensitivity to the research theme.

2. Transferability This criterion is closely related to whether research results can be applied to other similar situations. Thus, it is expected that the results of this study can be used as a reference for policy makers and policy implementers in other regions in planning and implementing similar policies.

3. Dependability. Dependency or reliability is a requirement for validity. Only with reliable data, valid data can be obtained. The main tool in qualitative research is research itself. Therefore, to guarantee the dependence and certainty of the results of research, the thing that needs to be done is to integrate the criteria of dependency and certainty. For this reason, researchers will provide materials, as stated by Nasution as follows:

- Raw data, such as field notes when conducting observations and interviews, recordings, documents, photographs and others which are processed in the form of field reports;

- Results of data analysis in the form of summaries, working hypotheses, concepts and so on;

- Synthesis of work results, such as interpretations, conclusions, definitions, interrelationships, data, themes, patterns of relationships with literature and final reports;

- Notes on the process used, namely on the methodology, design, strategy, procedures, rational, efforts so that the research can be trusted, as well as efforts to conduct an audit trail.

4. Confirmability to obtain certainty, it is necessary to carry out confirmation with the Supervising Commission Lecturer (Promoter and Co-Promoter) in the form of supervision in the field and consultation of research results that have been outlined in written form for discussion and get various suggestions from the supervisory commission (Promoters and Co-Promoters).

Data Analysis and Interpretation. According to the data analysis model of Miles, Huberman, and Saldana (2014) [38], Analysis consists of four activities, namely data collection, data condensation, data presentation, and conclusion drawing / verification (conclusion drawing / verification):

1. Data Collection (Data Collection);

2. Data Condensation;

3. Data Presentation (Data Display);

4. Conclusion Drawing / Verification (Conclusion Drawing / Verification).

The final step is drawing conclusions from verification. Based on the data that has been condensed and presented, researchers make conclusions that are supported by strong evidence at the data collection stage. The conclusion is the answer to the formulation of the problem and the question that has been raised by the researcher from the beginning. The following is an analysis of Miles, Huberman and Saldana (2014) interactive model data:

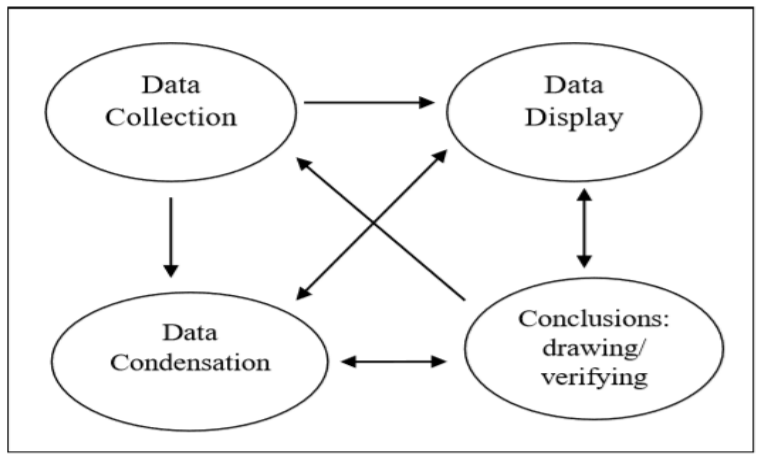

Figure 3 - Components of Interactive Model Data Analysis

(Sources: Miles, Huberman and Saldana, 2014) 


\section{RESULTS OF STUDY}

Sustainable palm oil governance from the policy level, industry level and plantation level is integrated and implemented in a system called Indonesia Sustainable Palm Oil (ISPO). ISPO is a form of change management carried out by the Indonesian government in handling oil palm.

The palm industry is a vital and controversial part of the current trajectory of Indonesia's economic growth. The discussion of economic benefits compared to social and environmental costs is increasingly polarized, and the situation is exacerbated by critics and vocal supporters who insist on extreme positions to pursue very different agendas. What is hidden in the current debate is the many similarities between these conflicting perspectives, where significant improvements can be made in palm oil governance in Indonesia, which will provide direct benefits to the environment, local communities, and the overall performance and reputation of the industry.

Global market demand for palm oil is driving Indonesia to accelerate the expansion of large-scale oil palm plantations. Data from the Directorate General of Plantations shows that in the past ten years, the area of oil palm plantations has almost doubled from 6.7 million hectares in 2007 to 11.6 million hectares in 2016. The spread of oil palm as presented in Figure 5.

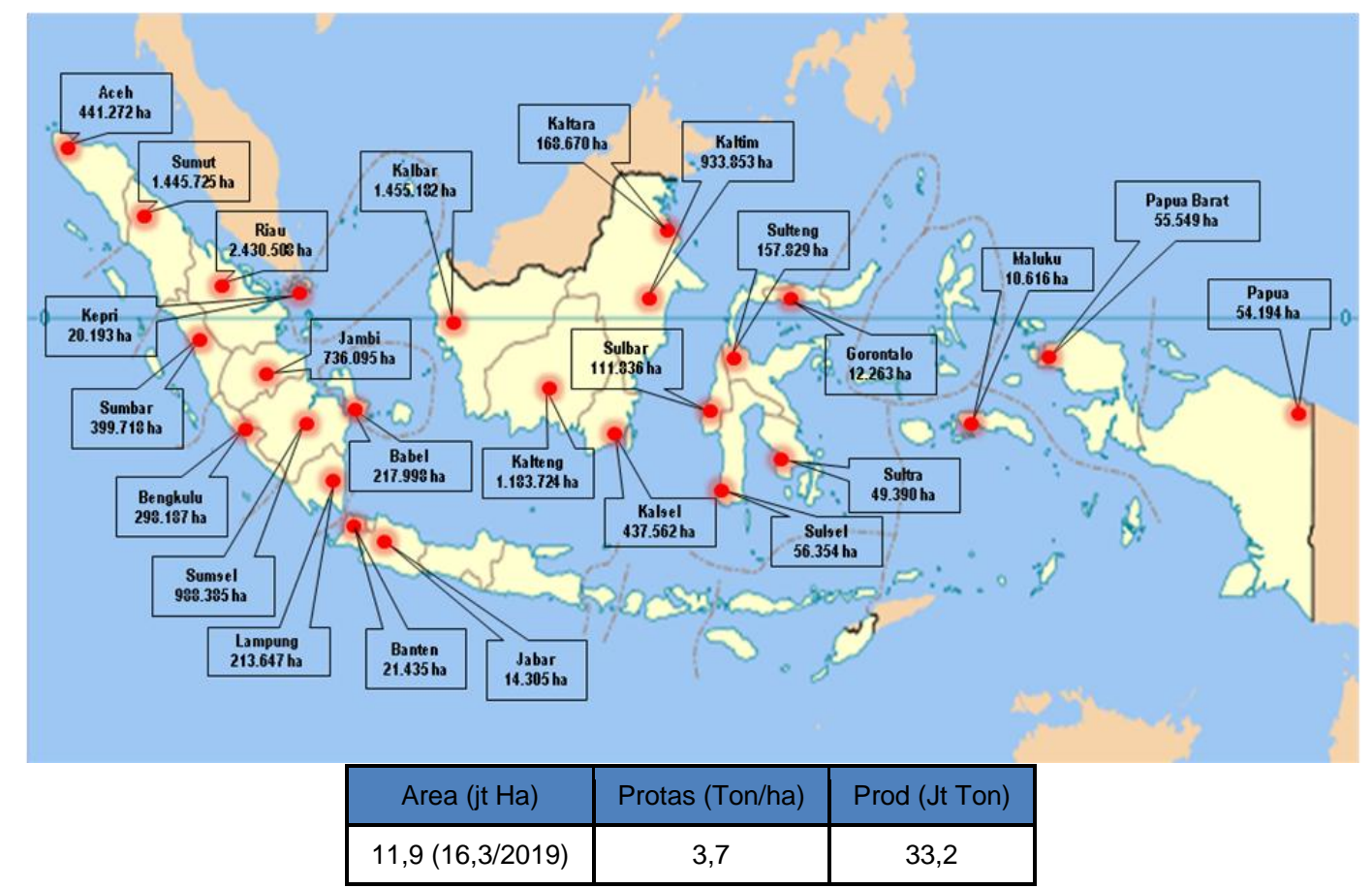

Figure 4 - Distribution of Palm Oil in Indonesia (Source: Plantation Statistics 2015 - 2018)

Palm is a super commodity that supports regional and national economic growth. Palm contributes Rp 280 trillion in exports with an area of 11.9 million ha (2016). However, a fire in the preparation of land and oil palm plantations led the Indonesian President to issue a moratorium on the issuance of new licenses for the expansion of oil palm plantations. Previously, the government launched ISPO (Indonesian Sustainable Palm Oil) in 2011 to develop oil palm plantations that are economically, socially and environmentally friendly. Until 20115 only about $20 \%$ of plantations were ISPO-certified.

The development of the ISPO-certified oil palm plantation company, as explained by the Rambo Sawit Watch Team as follows:

"... ISPO Phase 1 certified oil palm plantations, in 2013 there were 10 companies increased to 40 companies in 2014, and rose quite dramatically in 2015 to 142 companies, until 2016 rose again to 184 companies..." ( Interview, October 2019). 
Plantations that have implemented the ISPO system, apparently cannot be guaranteed to have been freed from deforestation and social conflict, because the area of oil palm plantations that have not obtained ISPO certificates is much wider, which is 10.1 million hectares. This is as stated by the Rambo Sawit Watch Team as follows.

"...Until 2016, of the 11.6 million hectares of total oil palm plantations in Indonesia, there were only 1.5 million hectares of the area that have tried to apply the principle of sustainability under the ISPO system. Even plantations that have implemented the ISPO system, apparently cannot be guaranteed to have been freed from deforestation and social conflict. This is ironic because the area of oil palm plantations that have not yet received an ISPO certificate is much broader, which is 10.1 million hectares. That is, the potential for the destruction of natural forests and the escalation of social conflicts in the palm oil development sector in Indonesia will still not change significantly... " (Interview, October 2019).

Based on the field findings and interviews above, it is known that until now, the implementation of the ISPO system is still considered to be very slow. As of 2016, around 800 oil palm plantation companies are still in the registration stage, while 115 other companies are still in the process of being assessed. The number of companies that have not yet received ISPO certificates is estimated because many requests or applications for certificates accumulate in the ISPO secretariat. This is as stated by the Palm Oil Watch Team as follows:

"...the slow development of oil palm plantation companies that are ISPO-certified because the assessment process of companies that have registered ISPO is running slowly so that the ISPO certificate submission files have piled up in the ISPO secretariat, the slow assessment because many companies have not yet completed ISPO requirements. Besides that, the ISPO commission has too much authority..." (Interview, October 2019).

Meanwhile, in the context of the response to deforestation, the presence of oil palm plantations which in the past decade has seized 11.6 million hectares of land in Indonesia has also played a major role as a contributor to deforestation. In the 2009-2013 period, at least 516 thousand hectares of land were deforested within oil palm plantation concessions or 22 percent of total deforestation within the concession. Whereas in the same period ISPO was formed (2009), introduced (2011), and began to be implemented since 2012. This is as conveyed by Aman from Forest Watch Indonesia (FWI Document) as follows:

"...The growth of oil palm plantations also contributed to deforestation, because in general land clearing is carried out through third party fires..." (Documents and Mediation, October 2019).

Not only causes deforestation, the presence of oil palm plantations also has a big role in the emergence of various agrarian conflicts. Throughout 2018, this was stated by the Directorate General of Legal Relations of the Arrangement - Ministry of ATR as follows:

"...The Agrarian Reform Consortium (KPA) notes that there have been at least 252 agrarian conflicts with a total area of 400,000 hectares of conflict area and involving at least 108,714 households (KK). Half of them or 127 conflicts occur in the plantation sector with a total area of conflict of 302 thousand hectares... "(KPA mediation study document, October 2019).

This confirms that continuing the expansion of oil palm plantations in the future will continue to cause and exacerbate the Agrarian crisis.

Clearing and preparing land for oil palm plantations so far is still mostly done by burning land. This is as conveyed by Aman from Forest Watch Indonesia as follows:

"... 2.6 million hectares of land and forest have been burned between June and October 2015. This means that an area of more than four times the area of Bali burned in just five (5) months... "(Mediation Study Document, October 2019).

The islands of Sumatra and Kalimantan, which are part of the peat ecosystem, are the islands that experienced the most extensive forest fires. The provinces of South Sumatra and Central Kalimantan represent 23 percent and 16 percent of the total area burned. This is as explained by Aman from Forest Watch Indonesia as follows: 
"...we found that in the last 10 years, from 2006-2016, the highest number of hotspots were in the area of Sumatra and Kalimantan oil palm plantations, some of which are peat ecosystems... " (Media Study Document, October 2019).

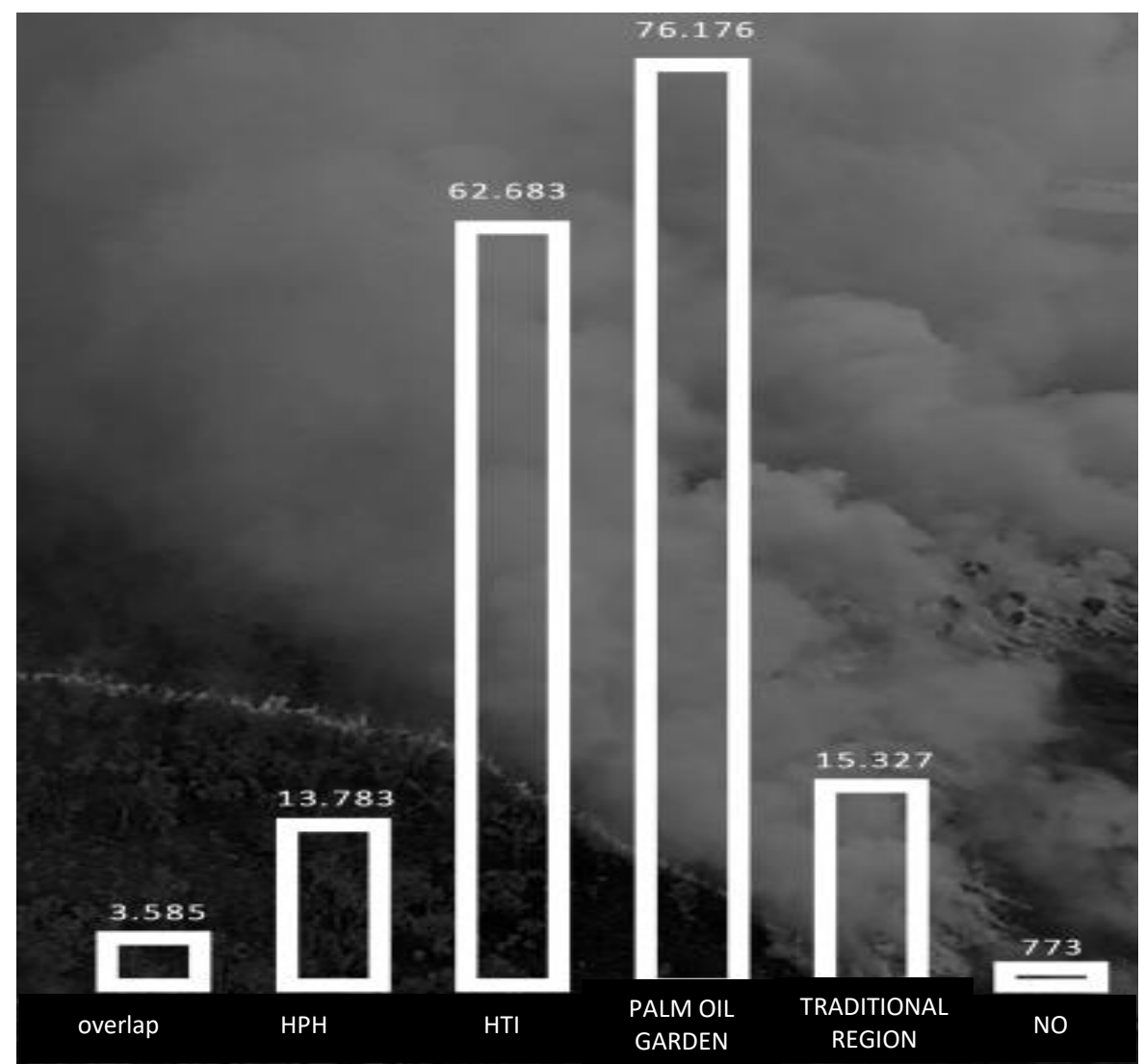

Figure 5 - Number of Hotspots in Indonesia for the period 2006 - 2016 (Source: FWI 2018)

Generally, land clearing for oil palm plantations is done by burning because the costs are cheap and the process is fast, as conveyed by Herry Purnomo from Forest Watch Indonesia as follows:

"...opening up land by burning is a favorite choice because it is cheap and the process is fast. While clearing and processing land with heavy equipment will require expensive costs. Even more expensive if the garden is on peatlands, where processing is clearly far more difficult ......" (Mediation Study Document, October 2019).

The expansion of oil palm plantations has been criticized for having a negative impact, especially in the form of forest destruction and human rights violations. The impact of plantation expansion as conveyed by Herry Purnomo from FWI is as follows:

"...the impacts of the expansion of oil palm plantations include forest and land fires due to the opening of oil palm plantations, loss and destruction of forest and peat land cover, threatened biodiversity, health problems due to haze from land fires, and subsequent impacts such as potential floods or landslides due to loss of buffer forest area... "(Mediation Study Document, October 2019).

Impacts in the form of human rights violations generally arise due to land tenure issues, namely the claiming of indigenous or local community land by industry or palm oil entrepreneurs, even by the State. In the post-1998 reform period, the issue of customary land has not subsided, has become even more complex, and customary land has been fragmented in the form of state plantations, agricultural land, indigenous peoples' lands, and people's claims. This is as conveyed by Herry Purnomo from Forest Watch Indonesia as follows:

"...Human rights violations in oil palm plantations are not only related to land tenure rights such as the claiming of indigenous or local community land by industry or oil palm 
entrepreneurs, even by the State, but also related to practices of oil palm plantations that are not transparent, especially in the core scheme -plasma often harms the community..." (Mediation Study Document, October 2019).

The potential for corruption in the palm oil sector is very high. This is a consequence of the long process of obtaining permits for oil palm plantations, which creates a gap for bribery and corruption at various stages of licensing. This is as stated by the Deputy for Prevention of the Corruption Eradication Commission as follows:

$" . .$. The potential for corruption in the palm oil sector is very high. This is because the process of licensing oil palm plantations is long, so that there are gaps to practice bribery and corruption at various stages of licensing... "(Mediation Study Document, October 2019).

The prospect of sustainable Indonesian Palm Oil Management in the perspective of Collaborative Governance. Palm is Indonesia's strategic industry. The strategic position of the oil palm is not a discourse or plan. Indonesian palm oil is indeed strategic because of the real condition of the industry and the performance it has demonstrated. This was stated by Bayu Krisnamurti as follows:

"Indonesian palm oil creates up to more than four million direct employment opportunities for farmers and laborers, with around twelve million indirect employment opportunities. Oil palm farmers also enjoy income that reaches four to seven times greater than the income of other crop farmers in the same location. This condition makes the World Bank records Indonesian palm oil as a real contributor to poverty reduction in various regions over the past 30 years... "(Mediation Study Document, October 2019).

What has been achieved by Indonesian Palm Oil today, cannot be separated from what has been determined by decision makers in the past. Palm stakeholders sit together to collaborate to determine the prospects for Indonesian palm oil going forward. This was stated by Bayu Krisnamurti as follows:

"...about 10 years ago, oil palm leaders; association leaders, farmer representatives, owners of large oil palm companies, and high-ranking government officials, agreed with a vision that was formulated in a simple but powerful message: by 2020 Indonesia will produce palm oil equivalent to 40 million tons of CPO and palm oil biofuel will reach $10 \%$ of the total demand for palm oil. The vision was then realized by starting to implement export duty policies progressively, thereby encouraging the development of downstream industries. Furthermore, the government issued a mandatory policy on mixing Biodiesel B5 which gradually became B20 along with the prospect of mixing Bioethanol $20 \%$ by $2020 . . . "$ (Document 2016 - Mediation Study October 2019).

In the midst of opportunities and success, the challenges and even threats facing oil palm are far greater and more real today. There are three main things that become the challenges and threats, as stated by Bayu Krisnamurti as follows:

"Challenges and threats to the development of Indonesian palm oil include, among others, (1) Indonesian palm oil is challenged to provide firmer and clearer evidence that palm oil is not only not a cause of fire and forest destruction, but also a leading activist in preventing the fire. (2) Indonesian palm oil faces the fact that the price of petroleum will be in the range of USD 30 - USD 50 per barrel as a new normal condition. This will cause palm biodiesel to face great challenges in maintaining its competitiveness. (3) Third, negative campaigns about oil palm in large consumer countries, which are primarily driven by the interests of competition and protectionism to protect their own products, continue to threaten the smooth trade and sale of Indonesian palm products..." (Mediation Study Document, October 2019).

What are the prospects for Indonesian palm oil in the future? The government together with Indonesian palm actors / stakeholders has established Indonesian Palm Oil Vision 2045, as stated by Bayu Krisnamurti as follows:

"The vision of Indonesian palm oil in 2045, namely: (1) productivity vision, the Indonesian oil palm we want is productive palm oil, optimally utilizing the gifts of natural land, water and sunlight to the amount of products that are beneficial to humans. And through this productivity, by 2045 Indonesia's palm oil production will be 60 million tons equivalent to CPO. (2) sustainable vision. The sustainability of Indonesian palm oil will rely on the 
principles of the Sustainable Development Goals established by the United Nations, which maintain a balance between the interests of the community, the environment and business people. Operationally the sustainability of Indonesian Palm Oil will continue to be based on ISPO. With that we can direct that in 2045 Indonesia will only produce and sell $100 \%$ sustainable palm oil. (3) value added vision. Indonesian palm oil will become an industry that optimizes added value. Indonesian palm oil not only produces oil either CPO or PKO but also all valuable production, such as gas for electricity, biomass for various purposes, new products such as plastic, paper and wood, and even gives value to the role of carbon extraction or environmental services other. In 2045 Indonesian Palm will become an integrated multiproduct industry. (4) welfare vision. In 2045 Indonesian Palm Oil will maintain the balance of the role of People's Plantation (PR), Private Large Plantation (PBS), State Large Plantation (PBN) at a ratio of around $50 \%, 45 \%, 5 \%$. With this new equilibrium condition, Indonesian Palm Oil will ensure that the welfare of all involved can be truly maintained in accordance with their roles and contributions. In 2045, oil palm farmers must obtain optimal benefits from multiproducts produced by oil palm plantations, not just rely on CPO prices. (5) institutional vision. The completeness of the Indonesian Palm Oil institutional component must be maintained at this time, namely by the clear role of farmers, entrepreneurs, government and professionals (such as researchers, auditors / certifiers, educators and non-government organizations). Palm associations and organizations are increasingly active and taking roles as professional owners in taking oil palm development. The steering committee and supervisors of the government also provide regulatory guidance that is increasingly conducive to industrial development. More and more professionals are becoming palm oil professional farmers and actively increasing product productivity and quality. In 2045 Indonesian Palm Oil institutions lead and be active as the main pillar of oil palm development." (Document 2016 - Mediation study October 2019).

\section{DISCUSSION OF RESULTS}

The palm industry is a vital and controversial part of the current trajectory of Indonesia's economic growth. The discussion of economic benefits compared to social and environmental costs is increasingly polarized, and the situation is exacerbated by critics and vocal supporters who insist on extreme positions to pursue very different agendas. What is hidden in the current debate is the many similarities between these conflicting perspectives, where significant improvements can be made in palm oil governance in Indonesia, which will provide direct benefits to the environment, local communities, and the overall performance and reputation of the industry.

Development of sustainable Indonesian oil palm governance in the perspective of Collaboration Governance. Global market demand for palm oil is driving Indonesia to accelerate the expansion of large-scale oil palm plantations. Data from the Directorate General of Plantations shows that in ten years, the area of oil palm plantations has almost doubled from 6.7 million hectares in 2007, to 11.6 million hectares in 2016 and 16.7 million hectares in 2019. Plantation expansion palm oil certainly needs land, this is where forests become victims.

Palm is a super commodity that supports regional and national economic growth. In 2016 oil palm contributed to exports of $\mathrm{Rp} 280$ trillion with a garden area of 11.6 million ha. However, the fires in preparing land and replanting oil palm led the Indonesian President to issue a moratorium on the issuance of new licenses to expand oil palm plantations. Previously, the government launched ISPO (Indonesian Sustainable Palm Oil) in 2011 to develop oil palm plantations that are economically, socially and environmentally friendly. As of 2016 , around $20 \%$ of ISPO-certified industries.

As of 2016, of the 11.6 million hectares of total oil palm plantations in Indonesia, there were only 1.5 million hectares of the area that had tried to apply the principle of sustainability under the ISPO system. Even plantations that have implemented the ISPO system, apparently cannot be guaranteed to have been freed from deforestation and social conflict. This is ironic because the area of oil palm plantations that have not yet received an ISPO 
certificate is much broader, which is 10.1 million hectares. This means that the potential for damage to natural forests and the escalation of social conflicts in the palm oil development sector in Indonesia will not change significantly.

Until now, the implementation of the ISPO system is still considered very slow. As of 2016, around 800 oil palm plantation companies are still in the registration stage, while 115 other companies are still in the process of being assessed. The number of companies that have not yet received ISPO certificates is estimated because many requests or applications for certificates accumulate in the ISPO secretariat.

In this certification system, the authority of the ISPO Commission is too large. The ISPO Commission has the authority from forming the ISPO Secretariat, the Assessment Team, the Complaints Complaints Completion Committee, to forming an Arbitration / Appeals Panel. The ISPO Commission is also authorized to ensure all matters regarding certification body personnel, consulting institutions, training institutions, auditors, and accompanying consultants. Most importantly, the ISPO Commission is even authorized to determine and decide the results of ISPO certification. The enormous and broad authority and workload of the ISPO Commission ultimately affected its performance and slowed it down. In addition, such great authority also complicates this system in maintaining its independence and credibility.

Meanwhile, in the context of the response to deforestation, the presence of oil palm plantations which in the past decade has seized 11.6 million hectares of land in Indonesia (2016) has also played a major role as a contributor to deforestation. In the 2009-2013 period, at least 516 thousand hectares of land were deforested within oil palm plantation concessions or 22 percent of total deforestation within the concession. Whereas in the same period ISPO was formed (2009), introduced (2011), and began to be implemented since 2012.

Not only causes deforestation, the presence of oil palm plantations also has a big role in the emergence of various agrarian conflicts. Throughout 2015, the Agrarian Reform Consortium recorded at least 252 agrarian conflicts with a total area of conflict of 400 thousand hectares and involved at least 108,714 households (KK). Half of them or 127 conflicts occurred in the plantation sector with a total area of conflict area of 302 thousand hectares 17. This confirms that continuing the expansion of oil palm plantations in the future will continue to cause and exacerbate the agrarian crisis.

Clearing and preparing land for oil palm plantations so far is still mostly done by burning land. According to the government, 2.6 million hectares of land and forests were burned between June and October 2015. This means that an area of more than four times the area of Bali Island burned in just five (5) months.

The islands of Sumatra and Kalimantan, which are part of the peat ecosystem, are the islands that experienced the most extensive land and forest fires. The provinces of South Sumatra and Central Kalimantan represent 23 percent and 16 percent of the total area of land burnt19. FWI observations found that in the last 10 years, from 2006-2016, the highest number of hotspots were in the area of oil palm plantations.

Land clearing by burning is a favorite choice because it is cheap and the process is fast. While clearing and processing land with heavy equipment will require expensive costs. Even more expensive if the garden is on peatlands, where processing is clearly far more difficult.

This cheap method is the cause of forest and land fires, which have caused dangerous smoke that envelops Indonesian territory; disrupt the transportation, trade and tourism sectors; force the closure of schools; and certainly worsen the health of citizens. The severe forest and land fires in 2015 contributed significantly to the increase in greenhouse gas emissions in Indonesia and the world.

Since it was first developed in 2011 and then started to be implemented the following year, the ISPO system has not been able to block the high rate of deforestation in Indonesia. In the 2009-2013 period, Indonesia has lost 515.9 thousand hectares of natural forest due to the development of oil palm plantations. Sixty-three percent or 327.5 thousand hectares of which are in oil palm plantation concessions on Kalimantan Island. West Kalimantan 
Province is the province with the most deforestation, which is 147.6 thousand hectares, followed by Central Kalimantan 114.6 thousand hectares, East Kalimantan 34.2 thousand hectares, and Riau 32.4 thousand hectares.

Most of the land used by plantations comes from the lease-to-use forest area both in Other Use Areas (APL) and in Convertible Production Forests (HPK). This condition raises the potential for deforestation. At least for 2009-2013, APL and HPK contributed 1.1 million hectares of deforestation and 781 thousand hectare.

Various impacts of forest destruction and human rights violations by oil palm plantations continue to occur during the six years of ISPO. ISPO certification, which is expected to be a sign of improving forest and land governance, turns out to be merely producing ISPO certificates for its holders, without being accompanied by significant efforts to improve forest and land governance.

The weak performance of the ISPO certification system in an effort to improve the environmental and social performance of oil palm plantations in Indonesia, due to the fact that oil palm is one of the largest foreign exchange earner sectors besides oil and gas, coal, and tourism. However, it must also be seen that in fact in recent years, tax revenues from the oil palm plantation sector have continued to decline. This was triggered by the adoption of a zero percent export duty tariff for crude palm oil (CPO) exports below the price of USD750 / Metric Ton (MT), as mandated by the formation of the CPO Fund in 2015. Receipt of export duties has decreased, resulting in a decrease in income international trade to date.

In addition, there are also indications of a decline in international trade because the world market is still worried that Indonesian CPO is produced from concessions that are socially and environmentally problematic. Just imagine, until 2016, there were still 30 million tons of CPO production produced not in compliance with the principle of sustainability in the management of oil palm plantations. This amount is far greater than CPO production from oil palm plantations that have obtained ISPO certificates, which amount to a total of 7.4 million tons.

The Indonesian government hopes that the existence of ISPO will be able to answer these concerns, and restore public confidence, and increase the competitiveness of Indonesian palm oil in the world market. For this reason, the ISPO instrument must be strengthened immediately. ISPO as an instrument, can encourage oil palm plantations to increase productivity, improve legality, avoid conflicts and human rights violations, and contribute to Indonesia's commitment to prevent deforestation and reduce greenhouse gas emissions. Of course the first thing to consider is maintaining the credibility of the ISPO system.

The expansion of oil palm plantations has been criticized for having a negative impact, especially in the form of forest destruction and human rights violations. These impacts include forest and land fires due to the opening of oil palm plantations, loss and destruction of forest and peat land cover, biodiversity threats, health problems due to haze from land fires, and subsequent impacts such as potential floods or landslides due to loss buffer forest area.

Impacts in the form of human rights violations generally arise due to land tenure issues, namely the claiming of indigenous or local community land by industry or palm oil entrepreneurs, even by the State. In the post-1998 reform period, the issue of customary land has not subsided, has become even more complex, and customary land has been fragmented in the form of state plantations, agricultural land, indigenous peoples' lands, and people's claims. Human rights violations in oil palm plantations are not only related to land tenure rights, but also relate to practices of oil palm plantations that are not transparent, especially in the nucleus-plasma partnership scheme that often harms the community.

The potential for corruption in the palm oil sector is very high. This is a consequence of the long process of obtaining permits for oil palm plantations, which creates a gap for bribery and corruption at various stages of licensing.

The palm oil industry generates significant fiscal revenues for the government and encourages economic growth and infrastructure development at the local level. But on the other hand, the development of large-scale plantations has also caused various social 
conflicts and the occurrence of uneven distribution of economic benefits. However, the biggest impact of oil palm development is the potential damage to forest resources and environmental pollution.

In many cases, oil palm expansion is done at the expense of primary and secondary natural forests, and encroachment into peatlands. The result is a loss of biodiversity and massive greenhouse gas (GHG) emissions. Uncontrolled clearing of oil palm will trigger forest and land fires. Forest and land fires in Sumatra and Kalimantan in 2015 became the world's spotlight because of their impact on the environment and health threats to humans. The government has estimated that forest fires accounted for 63 percent of GHG emissions from Indonesia in 2015.

It has been eight years since ISPO has been implemented, but the benefits have not been seen clearly for the community and the environment. The ISPO system was developed to ensure compliance with Indonesian laws and regulations, both those that govern directly and those indirectly, but which relate to development in the palm oil sector. With this compliance, it is expected that palm oil commodities from Indonesia will be produced sustainably.

Therefore, the ISPO system really needs to strengthen its standards by referring to several relevant policies, such as: Law Number 14 Year 2008 Regarding Public Information Openness, Law Number 26 Year 2007 Regarding Spatial Planning, Law Number 41 Year 1999, Government Regulation (PP) Number 57 Year 2016 Regarding Protection and Management of Peat Ecosystems, Government Regulation (PP) Number 104 Year 2015 Regarding Procedures for Changing Designation and Function of Forest Areas, Presidential Instruction No. 8 of 2015 concerning Delays in Granting Licenses and Improving Governance Manage Primary Forests and Peatlands, MK Decision Number 45 of 2011 Concerning the Status of Designation and Designation of Forest Areas, and Joint Regulation (PerBer) of the Minister of Home Affairs, the Minister of Forestry (formerly the Minister of Environment and Forestry), the Minister of Public Works, and the Head National Land Agency (former Minister of Agrarian Affairs and Spatial Planning) in 2014 concerning Legal Instruments.

The negative impacts arising from the development of oil palm plantations encourage international institutions, markets and the wider community to demand that the practices of the oil palm plantation industry be carried out in a sustainable manner. The Indonesian government responded by issuing Minister of Agriculture Regulation No. 19 of 2011 junto No. 11 of 2015 concerning the Indonesian Sustainable Palm Oil (ISPO) Certification System.

The Indonesian government hopes that the existence of ISPO will be able to answer these concerns, and restore public confidence, and increase the competitiveness of Indonesian palm oil in the world market. For this reason, the ISPO instrument must be strengthened immediately. ISPO as an instrument, can encourage oil palm plantations to increase productivity, improve legality, avoid conflicts and human rights violations, and contribute to Indonesia's commitment to prevent deforestation and reduce greenhouse gas emissions. Of course the first thing to consider is maintaining the credibility of the ISPO system.

Prospects for Sustainable Palm Oil Management in the perspective of Collaboration Governance. Palm oil is one of the mainstay agricultural products in most parts of Indonesia and Indonesia is the largest palm oil producer in the world with a production level of more than 30 million tons in 2015, although the level of productivity is still below Malaysia. More than seventy percent $(70 \%)$ of total production is exported to international markets with the main export markets are India, Europe and China, as well as more than 60 other countries. In early 2017, the Indonesian government set a target of producing 40 million tons of crude palm oil by 2020.

In the global market, palm oil is a favorite vegetable oil compared to other vegetable oils because of the highest level of productivity. These global market needs have made the Indonesian palm oil sector contribute more than 15 billion dollars in annual revenues to total exports (3\% of Indonesia's GDP). The palm oil industry is also the direct livelihood of around 4 million families consisting of landowners and working farmers, and 16 million indirect 
working families. More than $40 \%$ of the palm oil industry consists of smallholders, which means that the palm oil sector has opportunities for increased development at the $p$ level.

Indonesian palm oil creates up to more than four million direct employment opportunities for farmers and laborers, with around twelve million indirect employment opportunities. Oil palm farmers also enjoy income that reaches four to seven times greater than the income of other crop farmers in the same location. This condition makes the World Bank records Indonesian palm oil as a real contributor to poverty reduction in various regions over the past 30 years.

What has been achieved by Indonesian Palm Oil today, cannot be separated from what has been determined by decision makers in the past. The form of collaborative governance by palm oil stakeholders has been carried out to determine the prospects for Indonesian palm oil going forward. About 10 years ago, oil palm leaders; association leaders, farmer representatives, owners of large oil palm companies, and high-ranking government officials, agreed with a vision that was formulated in a simple but powerful message: by 2020 Indonesia will produce palm oil equivalent to 40 million tons of CPO and palm oil biofuel will reach $10 \%$ of the total demand for palm oil. The vision was then realized by starting to implement export duty policies progressively, thereby encouraging the development of downstream industries. Furthermore, the government issued a mandatory policy on mixing Biodiesel B 5 which gradually became B20 along with the prospect of mixing Biofuel $20 \%$ by 2020.

However, Indonesian palm oil must never be careless. The lessons we have experienced in recent years show that amid the opportunities and successes, the challenges and even threats facing oil palm are far greater and more real today. There are three main things that become the challenges and threats:

First, Indonesian palm oil is challenged to provide clearer and more straightforward evidence that oil palm is not only not a cause of fire and forest destruction, but also a leading activist in preventing the fire.

Second, Indonesian palm oil must also face the fact that the price of petroleum will be in the range of USD30 - USD50 per barrel as a new normal condition. This will cause palm biodiesel to face great challenges in maintaining its competitiveness. On the other hand, cheap oil prices have also pushed down prices for various other commodities, including key palm competitors such as soybean oil and grain oil. Higher palm oil prices that differ too much from competing prices will disrupt palm oil's competitiveness.

Third, the negative campaign about palm oil in large consuming countries, which is mainly driven by the interests of competition and protectionism to protect their own products, continues to threaten the smooth trade and sale of Indonesian palm products.

Facing the above conditions, both the successes, opportunities and challenges, what are the prospects for Indonesian palm oil in the future? The governments together with Indonesian palm actors / stakeholders have established Indonesian Palm Oil Vision 2045, namely:

First, the vision of Indonesian palm productivity that we want is productive palm oil, making optimal use of the natural gifts of land, water and sunlight to the size of products that are beneficial to humans. The principle of "25-25" which is 25 tons of FFB and $25 \%$ yield is something that can be realized. An average of at least 5 tons of CPO per hectare for smallholder plantations nationally is another number that can be used as a reference. And through this productivity, by 2045 Indonesia's palm oil production will be 60 million tons equivalent to CPO.

Second, sustainable vision. The sustainability of Indonesian palm oil will rely on the principles of Sustainable Development Goals set by the United Nations, which maintain a balance between the interests of the community, the environment and business actors (planet, people, profit), not narrow and one-sided sustainability. Operationally, the sustainability of Indonesian Palm Oil will continue to be based on the existing ISPO, and will continue to be strengthened while improving in various aspects, ISPO must also be sought internationally, respected and respected. All systems related to the implementation of ISPO starting from the certification system, information system, audit system and so on must be 
realized. With that we can direct that in 2045 Indonesia will only produce and sell $100 \%$ sustainable palm oil.

Third, the added value vision. Indonesian palm oil will become an industry that optimizes added value. Indonesian palm oil not only produces oil either CPO or PKO but also all valuable production, such as gas for electricity, biomass for various purposes, new products such as plastic, paper and wood, and even gives value to the role of carbon extraction or environmental services other. In 2045 Indonesian Palm will become an integrated multiproduct industry.

Fourth, the vision of welfare. In 2045 Indonesian Palm Oil will maintain the balance of the role of People's Plantation (PR), Private Large Plantation (PBS), State Large Plantation (PBN) at a ratio of around $50 \%, 45 \%, 5 \%$. This condition will reverse compared to the current condition where PBS is around $50 \%$ and PR is $45 \%$. The reversal occurred because PR growth was indeed higher than PBS. With this new equilibrium condition, Indonesian Palm Oil will ensure that the welfare of all involved can be truly maintained in accordance with their roles and contributions. The welfare of oil palm farmers really must be realized to permanently eliminate poverty from oil palm plantation areas, both structural poverty and generational poverty. In 2045, oil palm farmers must obtain optimal benefits from multiproducts produced by oil palm plantations, not just rely on CPO prices.

Fifth, institutional vision. The completeness of the Indonesian Palm Oil institutional component must be maintained at this time, namely by the clear role of farmers, entrepreneurs, government and professionals (such as researchers, auditors / certifiers, educators and non-government organizations). Palm associations and organizations are increasingly active and taking roles as professional owners in taking oil palm development. The steering committee and supervisors of the government also provide regulatory guidance that is increasingly conducive to industrial development. More and more professionals are becoming palm oil professional farmers and actively increasing product productivity and quality. In 2045 Indonesian Palm Oil institutions lead and be active as the main pillar of oil palm.

In order to meet the world's demands for sustainable development, the Government of Indonesia has prepared a system of sustainable palm oil development or the Indonesian Sustainable Palm Oil System (ISPO). ISPO is a provision that will become a guideline for the Indonesian palm oil industry based on all environmental provisions in Indonesia and certification provisions in accordance with the International Standard Organization (ISO). Because ISPO is based on applicable laws and regulations, ISPO is determined as a mandatory or mandatory policy that must be implemented for all plantation businesses in Indonesia. Thus ISPO has a strong legal system and is evidence of compliance of plantation businesses to conduct business in accordance with applicable laws and regulations in Indonesia and is evidence of the commitment of plantation entrepreneurs to implement sustainable palm oil development

Based on the discussion above, a proposition regarding the development and prospects of sustainable Indonesian palm oil management can be formulated in the perspective of collaboration governance, as follows: "If the ISPO system organizer understands the regulations that underlie its activities and is consistent in operationalizing the regulations, the process of implementing the system ISPO can be realized well and conducive for all palm oil stakeholders, so that it will improve the quality of the Indonesian Palm Oil Governance Process that is Sustainable".

\section{CONCLUSION}

The growth of oil palm plantations has also led to various agrarian conflicts. The Agrarian Reform Consortium noted that at least 252 agrarian conflicts had occurred with a total area of 400 thousand hectares of conflict and involved at least 108,714 households (KK). Half of them or 127 conflicts occurred in the plantation sector with a total area of conflict of 302 thousand hectares. 
Indonesian Palm Oil creates up to more than four million direct employment opportunities for farmers and laborers, with around twelve million indirect employment opportunities. Oil palm farmers also enjoy income that reaches four to seven times greater than the income of other crop farmers in the same location. This condition makes the World Bank records Indonesian palm oil as a real contributor to poverty reduction in various regions over the past 30 years.

Challenges and threats of the development of Indonesian palm oil include, among others, (1) Indonesian palm oil is challenged to provide clearer and more straightforward evidence that palm oil is not only not a cause of fire and forest destruction, but also a leading activist in preventing the fire. (2) Indonesian palm oil faces the fact that the price of petroleum will be in the range of USD 30 - USD 50 per barrel as a new normal condition. This will cause palm biodiesel to face great challenges in maintaining its competitiveness. (3) Third, the negative campaign about palm oil in large consumer countries, which is mainly driven by the interests of competition and the prospect of Indonesian palm oil in the future can be realized protectionism to protect their own products, continue to threaten the smooth trade and sale of Indonesian palm products.

The government together with Indonesian palm actors / stakeholders in the form of the Indonesian Palm Oil Vision 2045, namely: (1) Productivity vision, by 2045 Indonesia's palm oil production will be 60 million tons equivalent to CPO; (2) Sustainable vision, in 2045 Indonesia will only produce and sell $100 \%$ sustainable palm oil; (3) Value added vision, by 2045 Indonesian Palm will become an integrated multiproduct industry; (4) Welfare vision. In 2045 Indonesian Palm Oil institutions lead and are active as the main pillar of oil palm development.

\section{SUGGESTIONS}

Application of compulsory certification for all plantation businesses. Not only applies to the plantation business operational phase, but also for the plantation business development phase. Certification assessment must be applied starting from pre-production (construction), production, to post-production (upstream-downstream). Requiring certification to all plantation businesses will facilitate the application of traceability to ensure that CPO production is obtained from ISPO-certified plantations;

Public participation and involvement of independent observers. The space for public involvement needs to be more clearly regulated in the ISPO system, including involvement in consultation activities to convey input and opinions by the parties, public participation in the context of the check and balance mechanism, and role space for independent observers;

Availability of certification information. The availability of information encourages public participation in guarding the implementation of a clean and credible ISPO system. The Ministry of Agriculture and the ISPO Commission as a public body have an obligation to open access to information for the public as mandated by the 2008 KIP Law. Specifically is the obligation to publish resumes of the assessment results by the Certification Body;

Add verifier and detailed assessment guide. To prevent differences in interpretations among auditors, it is necessary to measure measurable guidelines and add verifiers to ISPO principles and indicators. The Timber Legality Verification System (SVLK) can be used as a reference, where verification methods and assessment norms are regulated in regulations at the director level.

\section{REFERENCES}

1. Didiek, Goenadi, 2005, Kebijakan Perkebunan Masa Lalu, Pustaka Pelajar, Yogyakarta.

2. Dimas, Gadang. 2011. Analisis Peranan Sektor Pertanian terhadap Perekonomian Jawa Tengah. Jurnal Imliah Fakultas Ekonomi Universitas Diponegoro.

3. Dimas, Gadang. 2011. Analisis Peranan Sektor Pertanian terhadap Perekonomian Jawa Tengah. Jurnal Imliah Fakultas Ekonomi Universitas Diponegoro.

4. Didiek, Goenadi, 2005, Kebijakan Perkebunan Masa Lalu, Pustaka Pelajar, Yogyakarta. 
5. Mubyarto 1989, Pengantar Ekonomi Pertanian, Jakarta: Edisi Ke-tiga, LP3S.

6. Komisi ISPO. [2016]. Konsultasi Publik ISPO. [diakses tanggal 20 November 2019]. Tersedia pada:http://www.ispo-org.or.id/index.php?option=com_content\&view= article\&id=77\&ltemid=228\&lang=ina

7. Septian, Deni. 2015. Pengembangan Kebun Kelapa Sawit Syarat Potensi Korupsi. [diakses tanggal 20 Nopember 2019] Tersedia pada: http://bisnis.liputan6.com/read/2220750/pengembangan-kebun-kelapa-sawit-syaratpotensi-korupsi.

8. Kertas Posisi No.1/2010, ELSAM, Pelanggaran HAM di Kawasan Perkebunan Kelapa Sawit PT PP Lonsum Tbk-Sumatera Utara.

9. Santoso, Hery. Edy Sigit, Sutarta. and Hasril H, Siregar. 2006. Potensi Pengembangan Perkebunan Kelapa Sawit di Dataran Tinggi. Jurnal Penelitian Kelapa Sawit Vol 14 (2) hal 113-126.

10. Cheema, G. Shabbir. (2007). linking Government and Citizens through Democratic Governance" dalam Public Administration and Democratic Governance: Governments Serving Citizens. New York: 71h Global Forum on Reiventing Government Building Trust in Government, United Nations.

11. Bhatta, Gambir. (2006). International Dictionary of Public Management and Governance. New York: ME Sharpe Inc

12. Neo, Boon Siong \& Chen, Geraldine. 2007. Dynamic Governance: Embedding, Capabilities and Change in Singapore. Singapore: World Scientific Publishing Co.Pte. Ltd.

13. Pratikno, 2005. Good Governance and Governability, Jurnal Sosial Politik, Vol. 8 No. 3, Maret 2005 (231-248).

14. Prahalad, C.K. 2005. The Fortune at the Bottom of the Pyramid: Eradicating Poverty through Profits. Upper Saddle River, New Jersey (USA): Wharton School Publishing.

15. Rondinelli, D.A. (2007). "Government Serving People: The Changing Role of Public Administration in Democratic Governance" dalam Public Administration and Democratic Governance: Governments Serving Citizens. New York: $71 \mathrm{~h}$ Global Forum on Reinventing Government Building Trust in Government, United Nations.

16. Effendi, Sofian, 2002, Implementasi and Evaluasi Kebijakan Publik, Modul Kuliah MAPUGM, Yogyakarta.

17. Ansell and Gash. 2007. Collaborative Governance in Theory and Practice, Journal of Public Adminsitration Research and Theory. Published by Oxford University Press.

18. Khususiyah, dkk. (2009). Pengelolaan Hutan Bersama Masyarakat (PHBM): Upaya untuk Meningkatkan Kesejahteraan \& Pemerataan Pendapatan Petani Miskin di Sekitar Hutan. World Agroforestry Centre - ICRAF. Brief No. 02, Policy Analysis Unit.

19. Dewi, Novita, dkk, 2012, Kajian Keterlibatan Multipihak Dalam Pelaksanaan Peraturan Perundangan Mengenai Hutan Lindung Di Kabupaten Pangkep, Jurnal Analisis Kebijakan Kehutanan Vol.9 No.1, pp: 11-22.

20. Ade Febrian, Ranggi 2016, Collaborative Governance Dalam Pembangunan Kawasan Perdesaan, Tinjauan Konsep and Regulasi, WEDANA Jurnal Pemerintahan, Politik and Birokrasi, Vol. II. Nomor 1.

21. Cordery, J. 2004, Another case of the Emperor's new clothes? Journal of Occupational and Organizational Psychology.

22. Hartman, C., et al. 2002. Environmental collaboration: potential and limits. In T. de Bruijn \& A. Tukker (Eds.), Partnership and Leadership: Building Alliances for a Sustainable Future (pp. 21-40). Dordrecht: Boston: Kluwer Academic Publishers.

23. Moleong, Lexy J. (2007). Metodologi Penelitian Kualitatif. Bandung: PT Remaja Rosdakarya Offset.

24. Sugiyono (2015). Metode Penelitian Kombinasi (Mix Methods). Bandung: Alfabeta.

25. Sugiyono (2015). Metode Penelitian Kombinasi (Mix Methods). Bandung: Alfabeta

26. Lofland, John \& Lyn.H.Lofland. (1984). Analyzing Social Settings. California: Wadsworth Publishing Company. 
27. Koentjaraningrat. 1982. Pengantar IImu Antropologi. Jakarta: Aksara BaruSugiyono (2015). Metode Penelitian Kombinasi (Mix Methods). Bandung: Alfabeta.

28. Sugiyono. 2012. Metode Penelitian Kuantitatif Kualitatif and R\&D. Bandung: Alfabeta.

29. Sugiyono. 2012. Metode Penelitian Kuantitatif Kualitatif and R\&D. Bandung: Alfabeta.

30. Sugiyono. 2012. Metode Penelitian Kuantitatif Kualitatif and R\&D. Bandung: Alfabeta.

31. Moleong, L. 2014. Metodologi Penelitian Kualitatif. Edisi Revisi. Bandung: PT Remaja Rosdakarya.

32. Moleong, Lexy J. (1991) Metodologi Penelitian Kualitatif. Bandung: PT Remaja Rosdakarya Offset.

33. Miles, M.B, Huberman, A.M, Saldana, J. 2014. Qualitative Data Analisis: Methods Source Book. SAGE Publication. 